\title{
THE PARTITION OF INDIA AND ITS REFLECTIONS IN KHUSHWANT SINGH'S TRAIN TO PAKISTAN AND BAPSI SIDHWA'S ICE CANDY MAN: A COMPARATIVE STUDY
}

\author{
K. D. JADEJA \\ Lecturer in English, C.U.Shah University, Wadhwancity, India. \\ bhimkatta@gmail.com*
}

Review submitted in March/2015 and accepted in June/2015

DOI: $10.15628 /$ holos.2015.2814

\begin{abstract}
Partition of Indian Sub-continent is one of the most terrible events in the history of the sub continent. The Sub-continent got freedom in 1947 along with its vivisection on the communal basis which leaves us puzzled weather the year 1947 is worthy to be remembered for the independence or for the massacre and atrocities during involuntary migration of a huge mass of people for their existence. Various writers have attempted to deal with the theme of Partition of Indian Sub-continent in their works. However, a kind of variations in the depiction of the historical events, differences in the approaches to the truth and
\end{abstract}

differences in the focus and attitude of the authors are quite natural. Even the treatment of the same event or incident may differ from author to author. The present paper aims at the comparative study of Khushwant Singh's Train to Pakistan and Bapsi Sidhwa's Ice Candy Man. Both the writers have witnessed the event themselves and tried to depict the terror of the conflict and the suffering of people during those days in their novels. Both the writers have got worldwide recognition for their treatment of the theme of partition in their novels. The present paper discusses the similarities and dissimilarities in the treatment of the same theme.

KEYWORDS: Indian Sub-continent, freedom, vivisection, massacre, atrocities, involuntary migrations.

\section{PARTITION OF INDIAN SUB-CONTINENT}

Partition of Indian Sub-continent is one of the most terrible events in the history of the sub continent. The Sub-continent got freedom in 1947 along with its vivisection on the communal basis which leaves us puzzled weather the year 1947 should be remembered for the independence or for the massacre and atrocities during involuntary migration of huge masses of people for their existence.

Urvashi Butalia moves her reader by describing partition in the following words,

"The political partition of India caused one of the great human convulsions of history....... twelve million people moved between the new, truncated India and the two wings, East and West, of the newly created Pakistan...........Estimates of the dead vary from 200,000 to two million but that somewhere around a million people died is now widely accepted...75,000 women are thought to have been abducted and raped by men of religion different from their own (and indeed sometimes by men of their own religion.)"(Butalia 3)

Various writers have attempted to deal with the theme of Partition of Indian-sub continent in their works. However, a kind of variations in the depiction of the historical events, differences in the approaches to the truth and differences in the focus and attitude of the author 
are quite natural. An author is a product of society, as cultures, society, milieu, religion, author's social status and position and situation etc. form the mood and temperament of an author. Even the treatment of the same event or incident may differ from author to author. The present paper aims at the comparative study of Khushwant Singh's Train to Pakistan and Bapsi Sidhwa's Ice Candy Man. Both the writers have got worldwide recognition for their treatment of the theme of partition in their novels. The present paper discusses the similarities and dissimilarities in the treatment of the same theme.

\section{KHUSHWANT SINGH'S TRAIN TO PAKISTAN AND BAPSI SIDHWA'S ICE CANDY MAN: A COMPARATIVE STUDY}

Train to Pakistan (1956) is a novel wherein Khushwant Singh tells the tragic tale of the partition of India and Pakistan realistically. In fact the partition touched the whole country and Singh attempts to look at the tragic and terrible events from the point of view of the people of Mano Majra, a small village in Punjab, India. Ice Candy Man (1991) is also a novel depicting the conflicts in the sub-continent during the days of partition and their most damaging effects on the sub-continent. Here the story has been told from a Parsee's point of view. Khushwant Singh is an Indian writer, writing in English whereas Bapsi Sidhwa is a Pakistani writer. However both the novels share the same theme. Khushwant Singh (1915) was 32 years old and Bapsi Sidhwa (1939) was 8 years old at the time of partition. Both witnessed the partition themselves and tried to depict the terror of the conflict and the suffering of people during those days in their novels. Train to Pakistan and Ice Candy Man, both the novels are set in the year 1947. However, all the actions narrated in the novel Train to Pakistan take place in a small village in Punjab, India, whereas actions narrated in Ice Candy Man takes place in Lahore, Pakistan. Former is an Indian Sub-continental view of partition and later expresses Pakistani view of partition.

Khushwant Singh raises the curtain by giving an account of the summer of 1947 and what happens these days. Khushwant Singh uses the third person narration technique to maintain a kind of objectivity and to create a live moving picture before the eyes of the readers to witness it. By third person narration the writer gives more authenticity to the narration of the story. Here it can be noted that the writer begins novel favoring no religion, cast, political party instead focusing only on the misfortune of the Sub-continent and its inhabitants. The description here sometimes seems to be that of a history book. During these days Hindus and Muslims laid blame on each other. "Muslims said the Hindus had planned and started the killing. According to the Hindus, the Muslims were to blame."(Singh 1) However, the writer objectively states, "The fact is, both sides killed. Both shot and stabbed and speared and clubbed. Both tortured. Both raped." (Singh 1)

The writer uses first person narration technique to narrate the tear-jerking story of the partition in Ice Candy Man. It is the book, wherein Lenny, a polio stricken Parsee child living in Lahore, narrates the story of the partition conflict. Lenny, being a child of a Parsee family, roams freely through the Sikh, Muslim, Hindu, and Parsee society in Lahore. Being a lame receiving private schooling, she was always present at almost all places to witness every incident and to report them to the readers. Through an innocent child narrator and first person narration technique, the writer makes the description more authentic. The character of Lenny in the novel can be assumed as the writer herself that shows that the novel has autobiographical elements in 
it. Further the writer gives an argument to claim the truth in her story by saying that Lenny's tongue was truth inflected, "I am tempted to tell her the truth .... My wretched truth inflected tongue just in time." (Sidhwa 239)

Both the novels show that there were co-existence and harmony among the people belonging to different religions in rural areas before partition. The riots and partition destruction started from cities and reached to the small villages gradually. Both the novelists give the descriptions of pre-partition days of co-existence and harmony in the novels and gradually lead their reader to witness the conflicts and the tragedy that followed. Initially readers are informed about the conflicts through the conversation of the characters in the novels. So far the descriptions in both the novels become light some times and gloomy some times. In Train to Pakistan the writer makes the description light by introducing the love making episode between Juggat Singh and Nooran after the terrible description of professional robbery and Lala Ram Lal's murder. In the same way, Sidhwa makes the narrative quite light and pleasant by allowing Lenny to praise her brother Adi for almost two pages. When the description becomes quite serious in the novel Ice Candy Man, the author introduces a light event with comic elements and suddenly some event makes the description serious. Here only the pre-partition descriptions have light tone in both the novels. The instances given above are from the pre-partition description when actual partition has not been shown in the novel. However, both the writers hint at the up coming conflicts of riots and involuntary migrations of masses through the conversation between characters in the novels and then lead readers to witness the menacing and terrifying partition conflicts.

Both the writers show the people belonging to rural areas having no knowledge of either freedom or even partition. They are not interested in the politics of the sub-continent. However, bad characters like Ice Candy Man in Sidhwa's novel and Mali in Khushwant Singh's novel get the benefit of the partition chaos and create problems for others. Villagers in both the novels have a sense of belongingness and they don't want to migrate. They expect police and government to do some thing in the condition. Villagers in both the novels have a hope that all will be well after some time and they will come back to their own land. Here the description of involuntary migration of people makes readers fell as if they were themselves migrating from their mother land which brings tears in the eyes of readers. Descriptions of the partition destruction in both the novels are even more tragic. Descriptions include Arrival of Ghost train, funeral ceremony of dead bodies with kerosene and wood, burial of the dead bodies, evacuation of the villages and many more in Train to Pakistan and burning Lahore, evacuation of Pir Pindo, Rana's story and many more in Ice Candy Man.

Train to Pakistan shows the strange role of police department and officers during the days of partition. Officers are after money. They want all the Muslims of the area leave safely. What they are interested in is only their property. Indian officers are not even in favor of Indian government. Character of Hokum Chand, a magistrate shows the real character of the police department in India. Hokum Chand and Inspector are shown as corrupt officers expressing their views against the contemporary government, politicians, and Muslims. Iqbal is a timid socio political worker who comes to stop killing on the boarder area. He has been shown as a political agitator asking villagers to revolt against the contemporary government. He has been shown running after political glory and finally helpless in the situation and some times a ridiculous character in the novel. Here characters are giving their negative comments on the contemporary 
government and politicians and other religions but Khushwant Singh seems to remain neutral as he doesn't give any direct comment on any political ideology. The writer here even doesn't favor any religion directly.

In Ice Candy Man Bapsi Sidhwa shows her sympathy towards Jinnah and criticizes the personalities and characters of Gandhi and Nehru. She defends Jinnah who has been criticized for demanding a separate nation that led to partition of Indian Sub-continent. She does this task with the help of the dialogues of various characters in the novel and the narrator Lenny, who can be assumed as writer herself.

In the novel Bapsi Sidhwa shows Jinnah saying,

"You are free. You are free to go to your temples, your mosque or any other place of worship in the state of Pakistan. You may belong to any religion or caste or creed that has nothing to do with the business of state...etc...etc...Pakistan Zindabad!" (Sidhwa 144)

Bapsi Sidhwa has portrayed the character of Gandhi negatively in the novel. Here the author has depicted the character of Gandhiji talking only about enema. She presented Gandhiji announcing, "An enema a day keeps the doctor away."(Sidhwa87) The narrator has been shown by the author wondering in following words, "I am puzzled why he's so famous."(Sidhwa 87) Here, the portrayal of Gandhiji's character in the chapter shows that the novel 'Ice candy man presents a Pakistani attitude or the opinion about the character of Gandhiji who has been respected in India as the Father of the nation. Had the author been an Indian, she would have thrown light on other traits and qualities of Gandhiji's character and personality, instead of focusing only on his advice to flush stomach by enema. Further Ice-candy man expresses his doubt in the policy and character of English people. Ice-candy man expresses his doubt in the character of Nehru and his relation with Mountbatten and his wife

"Nehru, he's a shy one.....he's got Mountbatten eating out of his one hand and English's wife out of his other what-not....he's the one to watch!....... Nehru will walk off with the lion's share..."(Sidhwa131)

Here the writer clearly mentions that during division Muslims and Pakistan have suffered. The British government has done injustice to Jinnah and favored Nehru. Further, there are various jokes in the novel showing Hindus as timid and there are various comments that show Sikhs as cruel and blood thirsty and even the fighting arms of Hindus. The descriptions here are given from Pakistani point of view and writer sympathizes with Muslims, Pakistan and Jinnah. The novel can truly be called the Pakistani view of Partition.

In Train to Pakistan when people plan to attack a train leaving for Pakistan, no body could do anything lqbal a socio-political educated person, Meet Singh a priest at the Gurudwara, Hokum Chand a magistrate. All were helpless. A registered criminal Juggat Singh who believed in law of Karma saves the lives of his fellow villagers and he proves to be true to the Punjabi Code. Though he has been considered as a Badmas, he becomes a real hero and a savior who sacrifices his life to save the lives of his beloved Nooran and other Muslims leaving for Pakistan by the train. In Ice Candy Man, Sidhwa shows the role of Parsee characters that help Non-Muslim people to migrate safely from Lahore. Sidhwa portrays the character of God Mother as a savior who restores Ayah, a kidnapped Hindu lady from Heera Mandi, Lahore and manages to send her back 
to Amritsar. Thus Khushwant Singh shows a Sikh character, Juggat Singh as a savior of man kind and Sidhwa shows Parsee Characters, Lenny's parents and God Mother as the saviors of man kind.

Both the writers' objectives in the novels are to depict the partition destruction realistically in their novel. However love, romance and sex are also treated as themes in the novels and interwoven with the partition story. Khushwant Singh shows the real love between Juggat Singh and Nooran, people's love for their home land, religion, fellow villagers, lqbal's love for glory etc. Khushwant Singh describes love making episodes between Juggat Singh and Nooran and Hokum Chand and the prostitute girl. Here in the descriptions the writer has drown a line of limitation in describing the sexual activities. In Ice Candy Man, Bapsi Sidhwa shows Love for religion, love for land, (Ice Candy man and other people) love for power (Tara Singh), physical love that leads to passion/sex (Ayah's admirers including Ice Candy Man), and love for human beings (Parsee's role), Sufiana love (Ice Candy Man in the form of a fakir) and an unconditional love between Lenny and God Mother and Lenny's love for her cousin. Sidhwa shows the sexual activities between Ayah and her admirers, and Lenny and her cousin. Here in Ice Candy Man Sidhwa describes the sexual activities with a child narrator's innocence which makes some description almost porn description of the sexual activities.

\section{CONCLUSION}

With all these similarities and dissimilarities, Khushwant Singh's Train to Pakistan and Bapsi Sidhwa's Ice Candy man are the realistic description of the partition trauma and misfortune of the sub-continent, colored by their writers' imaginations. Train to Pakistan is an Indian Subcontinental view of partition whereas Ice Candy Man is a Pakistani view of partition. However, both the writers are equally capable of arousing the readers' sensibility towards the most tragic events of the partition and the problems created by the involuntary migrations in 1947.

\section{REFERENCES}

1. Butalia Urvashi. (1998). The other side of silence: voices from the partition of India. New Delhi, India: Penguin Books India (P) Ltd.

2. Dodiya Jaydeepsinh, (2010).Bapsi Sidhwa, Rajkot, Wide Margin Books.

3. Sidhwa, Bapsi. (1989). Ice Candy Man, New Delhi, Penguin books.

4. Singh Khushwant. (1989). Train to Pakistan. New Delhi, India: Time Books International. 